\title{
ANALISIS KREATIVITAS SISWA DALAM MEMECAHKAN MASALAH MATEMATIKA BERDASARKAN TINGKAT KEMAMPUAN MATEMATIKA DI KELAS
}

\author{
Johan Subur \\ Guru Sekolah Menengah Pertama Negeri Kabupaten Subang \\ johan_subur@gmail.com
}

\begin{abstract}
ABSTRAK
Penelitian ini berangkat dari latar belakang pemikiran mengenai perlunya meningkatkan hasil belajar matematika sebagai respon terhadap gejala melemahnya kualitas proses dan hasil pembelajaran matematika khususnya dalam proses pengembangan kreativitas siswa. Proses pembelajaran yang terpaku pada buku teks tanpa menelaah lebih jauh kreativitas siswa baik dari pemberian materi maupun soal matematika serta jarangnya pemberian soal pemecahan matematika mengakibatkan sulit diketahuinya perkembangan kreativitas siswa. Hal ini terjadi pada SDN Angkasa I Kecamatan Kalijati Kabupaten Subang. Oleh karena itu perlu pengkajian kreativitas siswa untuk mengetahui perkembangan kreativitas siswa berdasarkan kemampuan matematika siswa. Sehingga peneliti membuat judul penelitian ini Analisis Kreativitas Siswa Dalam Memecahkan Masalah Matematika Berdasarkan Tingkat Kemampuan Matematika Di Kelas VI. Penelitian ini bertujuan untuk mengetahui deskripsi kreativitas siswa berdasarkan tingkat kemampuan matematika siswa matematika siswa Kelas VI SDN Angkasa I Kecamatan Kalijati Kabupaten Subang. Dari hasil penelitian, kemampuan matematika siswa mempengaruhi kreativitas siswa, makin tinggi tingkat kemampuan matematika makin tinggi pula kreativitasnya.
\end{abstract}

Kata kunci: kreativitas, masalah matematika, kemampuan matematika, kelas VI sekolah dasar

\section{ABSTRACT}

This study departs from the rationale of the need for improving mathematics learning outcomes in response to symptoms of weakening the quality of processes and outcomes of learning mathematics in particular in the process of developing student creativity. The learning process that focused on textbooks without further examine students' creativity both from giving material and math problems as well as lack of provision makes it difficult math problem solving creativity of students known developments. This happens on SDN I district Kalijati Space Subang. Therefore it is necessary to know the students 'creativity assessment students' creativity development based mathematical skills of students. So the researchers made the title of this study Analysis Student Creativity In Problem Solving Based Mathematics Mathematical Ability Level VI classes. This study aims to determine the description of the creativity of students by ability level math students math students SDN Space VI Class I district Kalijati Subang. From the research, mathematical skills of students affects students' creativity, the higher the rate the higher the capability mathematical creativity.

Keywords: creativity, math problems, math ability, class VI elementary school

\section{PENDAHULUAN}

Matematika merupakan salah satu ilmu yang sangat penting. Karena pentingnya, matematika diajarkan mulai dari jenjang Sekolah Dasar (SD) sampai dengan perguruan tinggi. Bagi siswa selain untuk menunjang dan mengembangkan ilmu-ilmu lainnya, matematika juga dipergunakan untuk bekal terjun dan bersosialisasi dalam kehidupan masyarakat. Salah satu dari beberapa aspek yang terdapat dalam tujuan pembelajaran matematika dalam standar kompetensi kurikulum 2006 yang harus dikembangkan dalam diri siswa adalah kreativitas.

Kreativitas merupakan suatu bidang yang sangat menarik untuk dikaji namun cukup rumit sehingga menimbulkan berbagai perbedaan pandangan. Menurut Supriadi (2001) kreativitas didefinisikan secara berbeda-beda tergantung pada bagaimana orang mendefinisikannya. Tidak ada satu definisipun yang dianggap dapat mewakili 
pemahaman yang beragam tentang kreativitas atau tidak ada satu definisipun yang dapat diterima secara universal. Munandar (2009), menyatakan bahwa kreativitas adalah kemampuan untuk melihat atau memikirkan hal-hal yang luar biasa, tidak lazim, memadukan informasi yang tampaknya tidak berhubungan dan mencetuskan solusisolusi baru atau gagasan-gagasan baru yang menunjukan kefasihan, keluwesan, dan orisinalitas dalam berpikir. Ciri-ciri kreativitas dapat dibedakan menjadi dua yaitu ciri kognitif (aptitude) dan ciri non-kognitif (nonaptitude).Ciri kognitif dari kreativitas terdiri dari orisinalitas, fleksibilitas dan kefasihan. Sedangkan ciri nonkognitif dari kreativitas meliputi motivasi, kepribadian, dan sikap kreatif. Kreativitas yang baik meliputi ciri kognitif maupun ciri non kognitif merupakan salah satu potensi yang penting untuk dipupuk dan dikembangkan.

Kreativitas sebagai kemampuan untuk melihat kemungkinan-kemungkinan untuk memecahkan suatu masalah, merupakan bentuk pemikiran yang sampai saat ini masih kurang mendapat perhatian dalam pendidikan formal. Siswa lebih dituntut untuk berpikir linier, logis, penalaran, ingatan atau pengetahuan yang menuntut jawaban paling tepat terhadap permasalahan yang diberikan. Kreativitas yang menuntut sikap kreatif dari individu itu sendiri perlu dipupuk untuk melatih anak berpikir luwes (flexibility), lancar(fluency), asli (originality), menguraikan (elaboration) dan dirumuskan kembali (redefinition) yang merupakan ciri berpikir kreatif yang dikemukakan oleh Guilford (dalam Munandar, 2009).

Dalam kenyataannya, kreativitas siswa dalam matematika belum diperhatikan oleh guru. Berdasarkan hasil observasi pada SD Negeri Angkasa I, kegiatan pembelajaran sudah difokuskan pada siswa. Siswa dibentuk dalam kelompok belajar dan bertanggung jawab atas LKS yang diberikan guru. Namun soal yang diberikan sebatas pada materi yang diajarkan yang telah didahului dengan contoh oleh guru, bukan merupakan masalah matematika. Pemberian soal rutin seperti itu membuat siswa hanya menguasai teknik penyelesaian yang sudah dicontohkan sebelumnya dan tidak memberikan ruang bagi siswa berkreasi dengan pengalaman matematika sebelumnya.

Hal itu, sesuai dengan salah satu tujuan pembelajaran matematika menurut kurikulum 2006 yaitu agar siswa memiliki kemampuan memecahkan masalah yang meliputi kemampuan memahami masalah, merancang model matematika, memecahkan model dan menafsirkan solusi yang diperoleh. Masalah matematika hanya akan bisa dipecahkan jika siswa memiliki motivasi, kemampuan berpikir kreatif, keterampilan dan pengetahuan akan masalah yang diberikan di samping aspek lainnya. Dengan begitu kreativitas siswa yang ada pada siswa bisa diketahui dan dimunculkan. Seperti menurut Sternberg (2006) kreativitas sudah jelas terdapat pada anak-anak. Dengan demikian usaha kita untuk memunculkan kreativitas yang ada pada siswa semaksimal mungkin.

Mc Cabe (dalam Daniel Fasko, 2000) mengungkapkan bahwa ada hubungan antara tinggi skor IQ verbal dalam matematika dengan kreativitas yang tinggi yang diukur dengan Torrance Test of Creative Thinking (TTCT).

Sedangkan menurut Livne dan Milgram (2006) mengungkapkan bahwa kecerdasan umum dapat digunakan untuk memprediksi kemampuan matematika namun tidak dapat memprediksi kemampuan kreatif dan sebaliknya kemampuan kreatif tidak dapat memprediksi kemampuan matematika siswa.

Berdasarkan kenyataan ini, penulis tertarik untuk melihat dan mendeskripsikan kreativitas siswa dalam memecahkan masalah matematika berdasarkan tingkat kemampuan matematika. Kajian ini memungkinkan 
diperolehnya sumbangan pengetahuan baru dalam melihat kemampuan dan kreativitas siswa dan bagaimana memanfaatkannya. Sehingga kreativitas yang ada pada siswa bisa dimunculkan semaksimal mungkin.

\section{METODE PENELITIAN}

\section{Jenis Penelitian}

Penelitian ini adalah penelitian lapangan, yang artinya sebagai penelitian yang datanya diperoleh dengan cara mengumpulkannya dari pengalaman empiris di lapangan penelitian dengan pendekatan kualitatif. Jenis penelitian kualitatif ini adalah deskriptif, yang selanjutnya disebut deskriptif kualitatif, artinya bahwa penelitian ini bermaksud melakukan penyelidikan dengan menggambarkan atau melukiskan keadaan objek/subjek penelitian pada saat sekarang berdasarkan fakta-fakta yang tampak atau sebagaimana adanya (Robert, S Bogdan dan Sari Knope Biklan, 1982).

Metode ini digunakan untuk menggambarkan bagaimana kondisi di lapangan, proses apaapa saja yang telah berlangsung dengan cara diagnosa dan menerangkan hubungan yang terjadi di lapangan dengan kajian teori, untuk kemudian dapat ditarik kesimpulan dari masalah yang ada sekarang, yang kesemuanya disusun secara sistematis berdasarkan datadata yang telah dikumpulkan (Moleong, 2005).

\section{Subjek Penelitian}

Dalam penelitian ini, subyek penelitiannya adalah siswa kelas VI SD Negeri Angkasa I Kecamatan Kalijati Kabupaten Subang, sekolah yang sudah RSBI, sehingga peneliti tertarik untuk meneliti kemampuan kreativitasnya serta dari observasi lapangan ternyata guru masih mengalami kesulitan dalam mengembangkan kreativitas siswa, sehingga belum diketahui pasti bagaimana kretivitas siswa dalam memecahkan masalah.

\section{Tehnik Pengumpulan Data}

Tekhnik pengumpulan data yang digunakan dalam penelitian ini yaitu melalui dokumentasi dan wawancara. Teknik pengumpulan data tersebut dapat diharapkan dapat saling melengkapi, sehingga diperoleh suatu informasi yang diharapkan.

1. Tes

Menurut (Arikunto, 2006) tes adalah serentetan pertanyaan atau latihan serta alat lain yang digunakan untuk mengukur keterampilan, pengetahuan intelegensi, kemampuan atau bakat yang dimiliki oleh individu atau kelompok.

\section{Dokumen}

Dokumen adalah suatu teknik dimana data diperoleh dari dokumen-dokumen yang ada pada benda-benda tertulis seperti buku-buku notulensi, makalah, peraturanperaturan, buletin-buletin, catatan harian dan sebagainnya (Arikunto, 2006).

3. Wawancara

Esterberg (dalam Sugiyono, 2012) mendefinisikan wawancara adalah pertemuan dua orang untuk bertukar informasi dan ide melalui tanya jawab, sehingga dapat dikontruksikan makna dalam suatu topik tertentu. Pedoman wawancara tetap membantu para peneliti untuk berfokus pada topik penelitian. Kebebasan ini dapat membantu pewawancara untuk menyesuaikan pertanyaan-pertanyaan berdasarkan isi dan situasi kepada orang-orang yang diwawancara (Lindlof dan Taylor, 2002). Teknik pengumpulan data ini mendasarkan diri pada laporan tentang diri sendiri atau self-report atau setidaktidaknya pada pengetahuan dan atau keyakinan pribadi. Wawancara dapat dilakukan secara terstruktur maupun tidak terstruktur, dan dapat dilakukan melalui tatap muka (face to face) maupun dengan menggunakan telepon (Sugiyono, 
2012: 137).

\section{Instrumen Penelitian}

Dalam penelitian kualitatif ini, peneliti bertindak sebagai peran utama, serta penelitian ini lebih menekankan proses dan hasil dalam penelitian. Dalam penelitian ini digunakan instrumen pendukung sebagai berikut:

\section{Indikator Kreativitas}

Dalam penelitian ini kreativitas dilihat dari aspek proses kreatif dan poduk kreatif yakni kefasihan/kelancaran (fluency), keluwesan/luwes (flexibility), kebaruan (novelty) serta keterincian (elaboration).

\section{Soal Tes Kemampuan Matematika}

Instrumen ini digunakan untuk mengetahui kemampuan matematika siswa secara keseluruhan, butir soal tes ini tidak terbatas pada sebuah materi tertentu namun matematika secara umum yang pernah dipelajari siswa.

3. Soal Tes Pemecahan

Masalah Soal tes pemecahan masalah terdiri dari dua buah soal yang digunakan untuk mengetahui bagaimana siswa memecahkan masalah kemudian ditelusuri kreativitasnya berdasarkan indikator yang ditetapkan

4. Pedoman Wawancara

Pedoman wawancara dalam penelitian ini berupa pertanyaan garis besarnya saja.

\section{Analisis Data}

Teknik analisis data yang digunakan dalam penelitian ini adalah analisis data kualitatif, mengikuti konsep yang diberikan Miles and Huberman (Sugiyono, 2012). Miles and Huberman (Sugiyono, 2012), mengemukakan bahwa aktivitas dalam analisis data kualitatif dilakukan secara interaktif dan berlangsung secara terus menerus pada setiap tahapan penelitian sehingga sampai tuntas, dan datanya sampai jenuh. Aktivitas dalam analisis data, yaitu data reduction, data display, dan conclusion drawing/verification.

\section{Prosedur Penelitan}

Kegiatan penelitian tersebut dilakukan dalam tiga tahapan kegiatan pokok, yaitu:

1. Tahap Persiapan

1) Orientasi lapangan atau observasi ke sekolah

2) Pengkajian teori kreativitas dan penyusunan indikator kreativitas

3) Pengembangan instrumen

a. Menyusun kisi-kisi soal tes kemampuan matematika

b. Menyusun instrumen soal tes kemampuan matematika

c. Menyusun instrumen soal pemecahan masalah.

d. Validasi instrumen oleh ahli

e. Uji coba instrumen

f. Menyiapkan instrumen dan administrasi penelitian

2. Tahap Pelaksanaan Penelitian

Tahap ini adalah kegiatan utama penelitian yang meliputi :

1) Memberikan soal tes kemampuan metematika dengan tujuan memperoleh gambaran pengelompokan kemampuan siswa.

2) Pemilihan subjek berdasarkan tiap tingkat kemampuan matematika yakni masing-masing 2 siswa dari kelompok dengan kemampuan rendah, sedang dan tinggi.

3) Memberikan soal pemecahan masalah dan hasilnya akan dianalisis dengan indikator kreativitas dan diadakan wawancara terhadap subjek penelitian.

3. Tahap Penyelesaian

1) Mengolah dan menganalisis data hasil penelitian

2) Penyusunan laporan hasil penelitian 


\section{HASIL PENELITIAN}

1. Kreativitas Siswa Kemampuan Rendah Untuk Masalah Bangun Datar

Pada masalah bangun datar, subjek memenuhi dua aspek kreativitas yakni kefasihan dan keterincian. Aspek fleksibilitas tidak terpenuhi karena subjek tidak terbiasa mengerjakan masalah atau soal matematika bangun datar dengan cara yang biasa dipelajari di kelas.

2. Kreativitas Siswa Kemampuan Rendah Untuk Masalah Bilangan Bulat

Pada masalah bilangan bulat, subjek memenuhi dua aspek kreativitas yakni kefasihan dan keterincian. Subjek menampikan kreativitas yang kurang karena hanya mampu memenuhi dua indikator kreativitas. Siswa dengan kemampuan rendah memecahkan masalah atau membuat penyelesaian yang mudah dan menghindar dari kecenderungan halhal yang sulit. Hal ini diduga diakibatkan karena malas ataupun kurangnya latihan dalam mengembangkan kreativitas.

3. Kreativitas Siswa Kemampuan Sedang Untuk Masalah Bangun Datar

Pada masalah geometri, subjek memenuhi keempat aspek kreativitas yakni kefasihan, kebaruan, dan keterincian. Dibandingkan dengan subjek pada tingkat kemampuan rendah masalah bangun datar, subjek pada tingkat ini menunjukan perbedaan kemampuan dapat menunjang kemampuan untuk kreatif. Subjek juga menunjukkan ketertarikannya dengan memecahkan masalah matematika dengan menampilkan pemecahan masalah yang berbeda dengan subjek yang lain hanya saja sudut pandang dalam menyelesaikan masalahnya subjek masih kurang karena kebiasaan subjek yang selalu terpaku pada penyelesaian standar atau rumus yang biasa dipelajari di kelas.

4. Kreativitas Siswa Kemampuan Sedang Untuk Masalah Bilangan Bulat

Pada masalah aljabar, subjek memenuhi dua aspek kreativitas yakni kefasihan dan keterincian. Hampir serupa dengan siswa pada tingkat kemampuan rendah untuk masalah bangun datar, siswa pada tingkat kemampuan sedang pun tidak memenuhi dua aspek yang paling ditekankan atau merupakan tingkat teratas dalam mendefinisikan individu yang kreatif. Kecenderungan ini disebabkan siswa cenderung terpaku pada pola yang ada yakni dalam menggambar bangun ruang harus diketahui rumusnya. Siswa pada tingkatan ini pun tidak menunjukan kreativitas yang lebih dari tingkatan sebelumnya dimana hanya dua dari empat indikator yang dapat terpenuhi.

5. Siswa Kemampuan Tinggi Untuk Masalah Bangun Datar

Pada tingkat ini, siswa cenderung memenuhi keempat aspek kreativitas yakni kefasihan, kebaruan, fleksibilitas dan keterincian. Siswa pada tingkat kemampuan ini telah menunjukan perbedaan yang signifikan dengan kedua tingkat sebelumnya. Nampaknya siswa pada tingkat ini siswa menyukai tantangan menginginkan penampilan yang berbeda dengan tingkat yang lainnya dilihat dari jawaban subjek yang beda dari yang lainnya.

6. Siswa Kemampuan Tinggi Untuk Masalah Bilangan

Pada kemampuan ini subjek memenuhi tiga aspek indikator kreativitas yaitu kefasihan, fleksibilitas dan keterincian. Siswa pada tingkat kemampuan ini telah menunjukan perbedaan yang signifikan dengan kedua tingkat sebelumnya. Meskipun belum menemukan yang baru tapi memiliki cara yang banyak dalam menemukan jawaban untuk menyelesaikan masalah.

\section{KESIMPULAN}

Berdasarkan hasil analisis, peneliti menyimpulkan sebagai berikut:

1. Kreativitas siswa pada aspek proses dan produk dalam memecahkan masalah matematika dengan tingkat kemampuan 
matematika rendah siswa hanya mampu memenuhi dua indikator kreativitas yaitu kefasihan dan keterincian dari empat indikator kreativitas yang telah ditentukan.

2. Kreativitas siswa pada aspek proses dan produk dalam memecahkan masalah matematika dengan tingkat kemampuan matematika sedang. Subjek memenuhi tiga aspek kreativitas yakni kefasihan, kebaruan, dan keterincian dari empat

\author{
indikator kreativitas yang telah \\ ditentukan.
}

3. Kreativitas siswa pada aspek proses dan produk dalam memecahkan masalah matematika dengan tingkat kemampuan matematika tinggi. Pada tingkat ini, siswa cenderung memenuhi keempat aspek kreativitas yakni kefasihan, kebaruan, fleksibilitas dan keterincian. Meskipun masih ada kekurangan dalam menyelesaikan masalahnya.

\section{DAFTAR PUSTAKA}

Arikunto, S. (2006). Penelitian Tindakan Kelas. Jakarta. Bumi Aksara

Basuki, H. (2005). Pengembangan Kreativitas. [Online]. Tersedia: http:/repository.gunadarma.ac.id:8000/ kommit2004_psikologi_012_362.pdf. [18 November 2011]

Bogdan, R S. (1982). Qualitative Research for education an Introduction to Theory and Methods. Boston. Allynan Bacon

Depdiknas. (2006). Permendiknas Nomor 22 Tahun 2006 Tentang Standar Isi Sekolah Menengah Atas. Jakarta: Depdiknas.

Direktorat Jenderal Peningkatan Mutu Pendidik dan Tenaga Kependidikan, Depdiknas. (2008). Kreativitas. Jakarta: Depdiknas.

Fasko, D. (2000). Education and Creativity. Creativity Research Journal. Vol. 13, Nos. 3 \& 4, 317-327

Hardianti, T. (2010). Intelegensi dan Kreativitas, Adakah Hubungan di Antara Keduanya?http://edukasi. kompasiana.com/2010/11/18/intelegensi-dan kreativitas adakah-hubungan-di-antara-keduanya/

Hudoyo, H. (2001). Pengembangan Kurikulum dan Pembelajaran Matematika. Universitas Negeri Malang

Lindlof, T. R. \& Taylor, B. C. (2002). Qualitative communication research methods. Thousand Oaks, CA: Sage Publications

Livne and Milgram. (2006). Academic Versus Creative Abilities in Mathematics: Two Components of the Same Construct? [Online]. http://www.psychologieaktuell.com/fileadmin/download/ PschologyScience/2-2008/13_Holling.pdf. [7 Juni 2012]

Moleong, L.J. (2005). Metodologi Penelitian Kualitatif.Bandung. PT. Remaja Rosda Karya

Munandar, U. (2009). Pengembangan Kreativitas Anak Berbakat. Jakarta: Rineka Cipta

Robinson, J.R. (2008). Webster`s Dictionary Defenition of Creativity. Online Journal of Workforce Education and Development. Volume III. P 3-4

Shadiq, F. (2004). Pemecahan Masalah, Penalaran dan Komunikasi. Yogyakarta: Pusat pengembangan dan penataran guru.

Shadiq, F. (2004). Psikologi Pembelajaran. Yogyakarta: Pusat pengembangan dan penataran guru.

Sternberg, R. J. (2006). The nature of creativity. Creativity Research Journal. 18 (1). p. 93-94

Sugiyono. (2009). Statistika untuk penelitian.Bandung: Alfabeta

Supriadi, D. (2001). Kreativitas, Kebudayaan, dan Perkembangan Iptek. Bandung: ALFABETA 